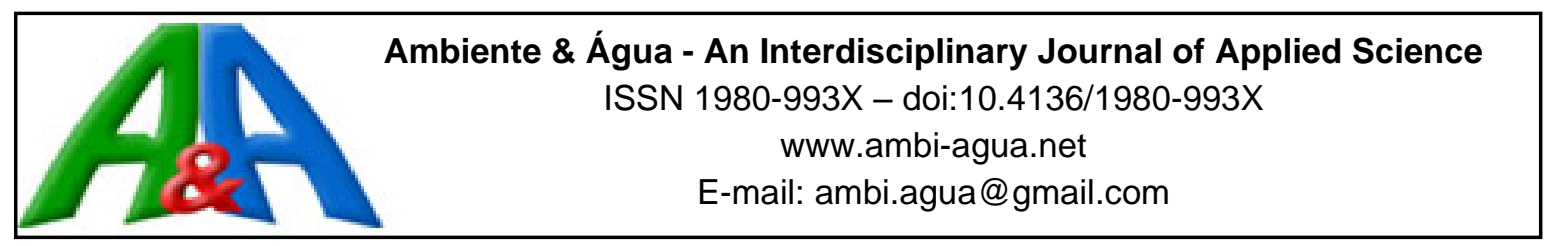

\title{
Connectivity as the control key to intensity of flood pulse in Taquari River oxbow lakes
}

ARTICLES doi:10.4136/ambi-agua.2534

Received: 21 Feb. 2020; Accepted: 22 Jun. 2020

\section{Adriana Maria Güntzel ${ }^{1 *}$; ; William Marcos da Silva2 ${ }^{2 D}$; Eliana Aparecida Panarelli ${ }^{3}$ iD}

\author{
${ }^{1}$ Laboratório de Estudos Territoriais. Universidade Estadual de Mato Grosso do Sul (UEMS), \\ Avenida Dom Antônio Barbosa, n 4155, CEP: 79115-898, Campo Grande, MS, Brazil. \\ ${ }^{2}$ Laboratório de Ecologia. Universidade Federal de Mato Grosso do Sul, Avenida Rio branco, $\mathrm{n}^{\circ}$ 1270, \\ CEP: 70304-702, Corumbá, MS, Brazil. E-mail: william.m.silva@ufms.br \\ ${ }^{3}$ Departamento de Ciências Exatas e da Terra. Universidade do Estado de Minas Gerais (UEMG), Avenida \\ Professor Mário Palmério, nº 1001(Bloco B), CEP: 38200-000, Frutal, MG, Brazil. \\ E-mail: panarelli1969@gmail.com \\ *Corresponding author. E-mail: amguntzel@uems.br
}

\begin{abstract}
The Taquari River is one of the most important tributaries of the Paraguay River, whose sediments are carried and deposited on the plain forming the largest alluvial fan in the world, known as Pantanal. In the floodplain, the course of the river has been modified by the sedimentation process, resulting in lakes with different degrees of connectivity with the river. This study assessed the influence of connectivity on the physical and chemical characteristics of water along a hydrological cycle in oxbow lakes of the Taquari River floodplain, in Mato Grosso do Sul, Brazil. Sampling was carried out monthly, from May 2005 to June 2006.The physical and chemical data of the water and the variables of river level and rainfall intensity were correlated by Principal Component Analysis (PCA). Limnological differences resulted from distinct degrees of connectivity between the oxbow lakes and the Taquari River. Variations in the dry and rainy seasons established a gradient that extends over a space-time continuum and generates greater environmental heterogeneity and, consequently, greater biodiversity. Thus we conclude that this mosaic of lakes and the surrounding landscape requires protection and preservation because of its importance for biodiversity conservation.
\end{abstract}

Keywords: river-lake interactions, tropical floodplain, upper Paraguay River basin.

\section{Conectividade como fator controlador da intensidade do pulso de inundação em lagoas marginais do Rio Taquari}

\section{RESUMO}

O rio Taquari é um dos afluentes mais importantes do rio Paraguai, cujos sedimentos são transportados e depositados na planície, formando o maior leque aluvial do mundo, conhecido como Pantanal. Na planície de inundação, o curso do rio vem sendo modificado por processo de sedimentação, resultando em lagos com graus distintos de conectividade com o rio. Este estudo teve como objetivo avaliar a influência da conectividade durante um ciclo hidrológico nas características físicas e químicas da água nos lagos meândricos da planície de inundação do 
rio Taquari, Mato Grosso do Sul, Brasil. As amostragens foram realizadas mensalmente, de maio de 2005 a junho de 2006. Os dados físicos e químicos da água e as variáveis nível do rio e intensidade da chuva foram correlacionados por PCA (Análise de Componentes Principais). As diferenças limnológicas resultaram de graus distintos de conectividade entre as lagoas e o rio Taquari. As variações nas estações seca e chuvosa estabeleceram um gradiente que se estende ao longo de um continuum espaço-tempo e gera maior heterogeneidade ambiental e, consequentemente, maior biodiversidade. Assim, concluímos que esse mosaico de lagos e a paisagem circundante requer proteção e preservação devido a sua importância para a conservação da biodiversidade.

Palavras-chave: bacia hidrográfica do Alto Paraguai, interações rio-lagoa, planície de inundação tropical.

\section{INTRODUCTION}

Floodplains are important regulators of water-level fluctuations and biogeochemical cycles. Marginal zones of floodplain are among the most productive habitats in the biosphere (Whittaker and Likens, 1975), and are also important centers of biological diversification (Junk, 1997). Such systems are characterized by marked seasonality of the water level, which drives variations in the energy and matter cycles in these ecosystems (Neiff, 1997). According to Junk et al. (1989) the intensity of changes promoted by these environments depends on the duration of the flood, size, position and connectivity among lateral water bodies and rivers.

Lateral systems have high residence time when compared to the river channel and are refuges for aquatic animals, providing important habitats for biological production and contributing to river biomass, as the floodplain communities increase the base of the river system food chain (Tockner and Stanford, 2002; Güntzel et al., 2010).

In these systems, oxbow lakes are a functional unit formed when the river channel is isolated by a cutoff of the meander loops (Wantzen et al., 2005) and isolation increase along the time, resulting in lakes with distinct degrees of connectivity to the river (Lesack and Marsh, 2010; Panarelli et al., 2013).

Lesack and Marsh (2010) conducted long-term studies on lakes in the Mackenzie River Delta and observed that different connectivities imply different degrees of water renewal, affecting productivity and biodiversity of lakes, creating a continuum of connectivity in space and time. In the Taquari River system, Panarelli et al. (2013) observed that spatial heterogeneity in the floodplain favored biodiversity, but mainly in systems with lower anthropic influence.

Differences in time of isolation and connectivity increase the functional complexity of the river due to exporting different types of dissolved organic materials (Lynch et al., 2019). As a consequence, these environments are really a mosaic of aquatic biotopes with particular physical and chemical dynamics (Rodrigues et al., 2002).

Thus, understanding these complex dynamics is the basis for maintaining biodiversity and for proper management of these systems (Junk et al., 2014). Knowing the functioning of the floodplain contributes to the monitoring of changes in water quality and in biodiversity influenced by climate changes and to the prediction and prevention of anthropogenic impacts in the basin.

In this context, this study assessed the influence of connectivity along a hydrological cycle on the physical and chemical characteristics of water in oxbow lakes of the Taquari River floodplain, Mato Grosso do Sul, Brazil. 


\section{MATERIALS AND METHODS}

\subsection{Study Area}

The Taquari River is one of the most important tributaries of the Paraguay river. Its sources are located in the "Chapada das Emas" and in the "Planalto do Taquari" (altitude of $860 \mathrm{~m}$ ), in Mato Grosso State, Brazil. It is almost $800 \mathrm{~km}$ in length and crosses the Mato Grosso do Sul State from the northeast to the west, in the Midwest region of Brazil (Figure 1). On a plain, which begins close to the municipality of Coxim, the Taquari River begins a frontier between the two sub-regions of the Pantanal, the Pantanal of Nhecolândia (left bank) and the Pantanal of Paiaguás (right bank), where one of the largest alluvial fans in the world has resulted from the sediments carried and deposited by the river (Ab'Sáber, 2006). According to Padovani et al. (2005), the total solid discharge of the Taquari River in Coxim is 35,830 ton./day and the annual flow rate of the river in that site is about $402.2 \mathrm{~m}^{3} / \mathrm{s}$ (Galdino et al., 2005).
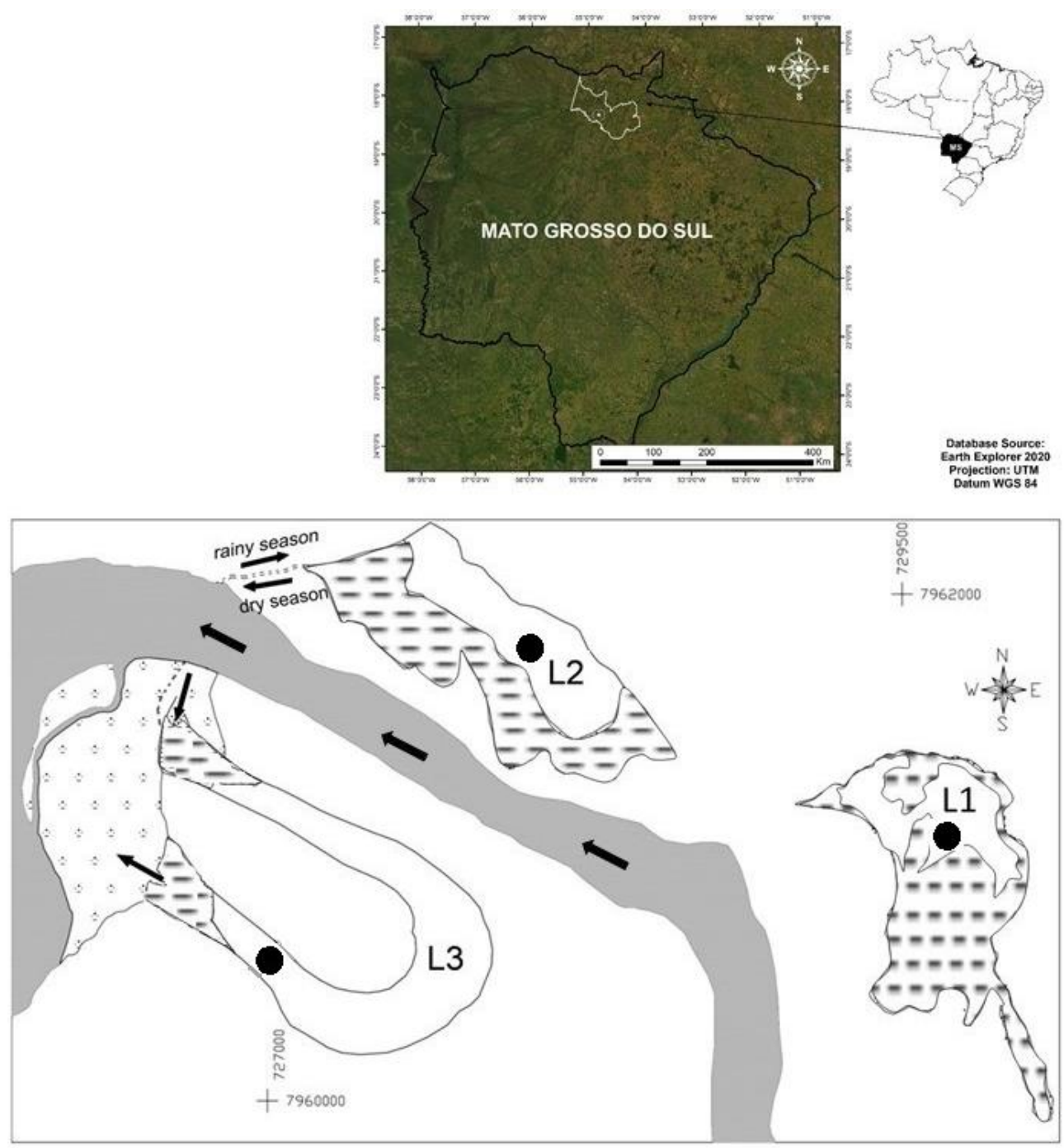

Legends:

\section{Taquari River}

$\square$ Lake area in dry season

\section{- Sample point}

$\rightarrow$ Water flow

\section{Lake area in rainy season}

Figure 1. Location of Mato Grosso do Sul State and study area in Coxim minicipality. L1 is the disconnected lake; L2 is the semi-connected lake and L3 is the permanently connected lake. Adapted from Panarelli et al. (2013). 
The catchment area of the Taquari River Basin covers $65,023 \mathrm{~km}^{2}$ and is located in a Köeppen classification Aw climate region, corresponding to a semi-humid tropical climate, with an annual mean temperature of $26^{\circ} \mathrm{C}$ and mean precipitation between 800 and $1600 \mathrm{~mm}$.year ${ }^{-1}$. There are two well-defined seasons in this region: the rainy season, from October to March, and the dry season, from April to September (Nimer, 1989). The location of the three lakes (L1, L2 and L3) in relation to the river channel is shown in Figure 1, where $\mathrm{L} 1=$ disconnected, $\mathrm{L} 2=$ semi-connected and $\mathrm{L} 3=$ connected. The oxbow lakes were characterized by low depths, being the maximum value observed in L2, which also had the largest surface area (Table 1). In these lakes, the surface area is reduced in the rainy seasons because of macrophyte development, as shown in Figure 2. For more information about the lakes, see Güntzel et al. (2010) and Panarelli et al. (2013).

Table 1. Geographical coordinates, altitude and morphometry of the oxbow lakes.

\begin{tabular}{lccc}
\hline & $\mathrm{L} 1$ & $\mathrm{~L} 2$ & $\mathrm{~L} 3$ \\
\hline Geographical coordinates & $18^{\circ} 25^{\prime} 38^{\prime} \mathrm{S}^{\prime} \mathrm{S}$ & $18^{\circ} 25^{\prime} 19^{\prime \prime} \mathrm{S}$ & $18^{\circ} 25^{\prime} 58^{\prime} \mathrm{S}$ \\
Altitude $(\mathrm{m})$ & $54^{\circ} 49^{\prime} 44^{\prime} \mathrm{W}$ & $54^{\circ} 50^{\prime} 41^{\prime} \mathrm{W}$ & $54^{\circ} 51^{\prime} 8^{\prime} \mathrm{W}$ \\
Surface área & 196 & 194 & 189 \\
Rainy period $\left(10^{3} \mathrm{x} \mathrm{m}^{2}\right)$ & & & \\
Dry period $\left(10^{3} \mathrm{x} \mathrm{m}^{2}\right)$ & 164.09 & 252.58 & 456.57 \\
Maximum depth $(\mathrm{m})$ & 526.49 & 601.92 & 574.97 \\
Minimum depth $(\mathrm{m})$ & 1.80 & 3.75 & 5.0 \\
Volume Rainy period $\left(10^{3} \mathrm{x} \mathrm{m}^{3}\right)$ & 1.0 & 0.8 & 1.4 \\
Dry period $\left(10^{3} \mathrm{x} \mathrm{m}^{3}\right)$ & 295.36 & 947.17 & $2,282.87$ \\
\hline
\end{tabular}
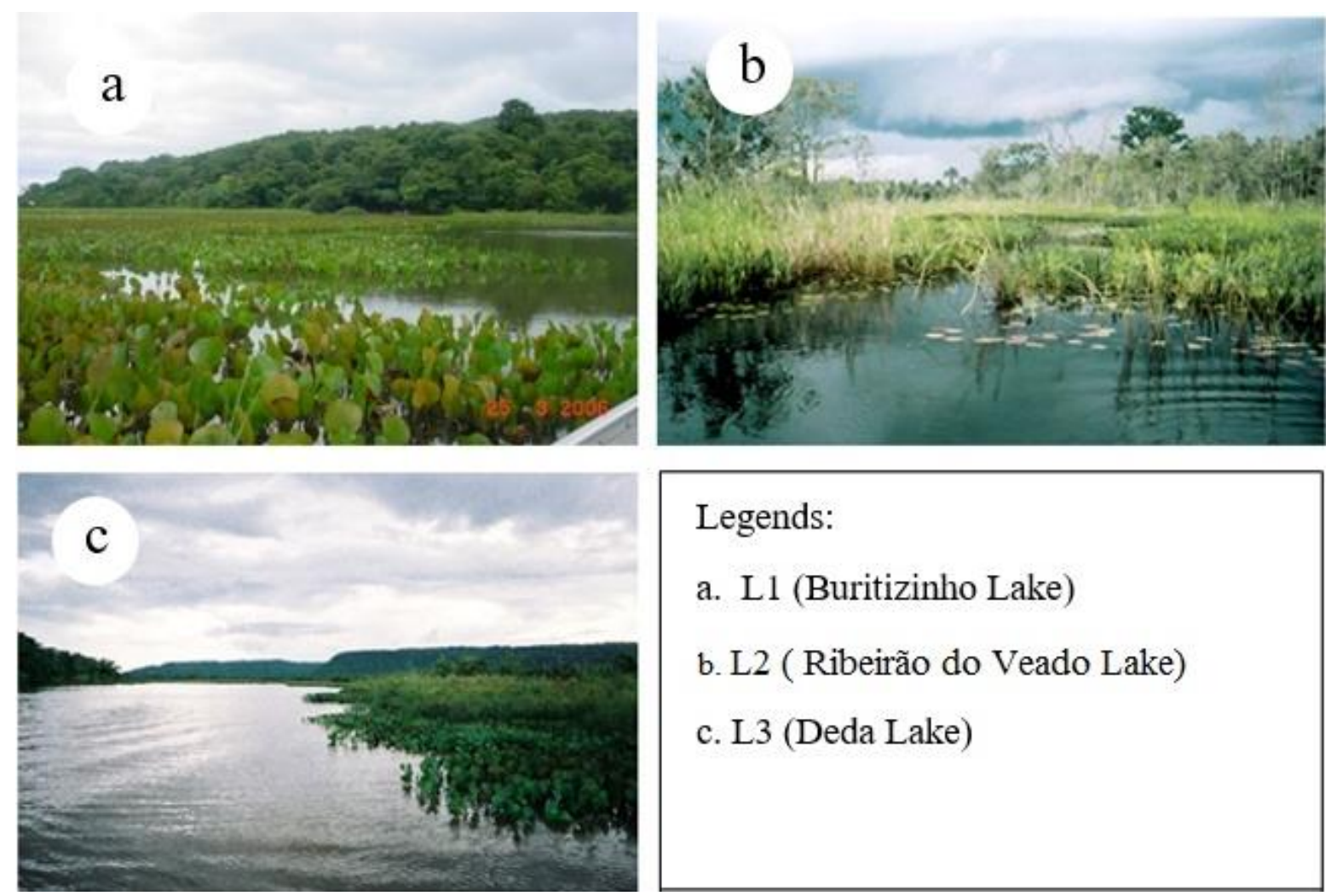

Legends:
a. L1 (Buritizinho Lake)
b. L2 ( Ribeirão do Veado Lake)
c. L3 (Deda Lake)

Figure 2. View of the oxbow lakes in March 2006 (rainy period), showing the presence of macrophyte stands at the littoral zone. 


\subsection{Limnological parameters}

Water sampling was carried out monthly, from May 2005 to June 2006, resulting in a total of 36 samples (12 for each lake). The methodology and equipment used for the water analysis are shown in Table 2. The samples were collected from the sub-superficial layer of the water and close to macrophyte stands, in the littoral zone of each lake. The water for analysis of nitrogen and phosphorus was stored in polyethylene bottles and fixed in sulfuric acid; samples for chlorophyll-a analysis were filtered in fiberglass filters and frozen.

Table 2. Variables and analysis methodology.

\begin{tabular}{ll}
\hline Variable & Methodology \\
\hline Water temperature $\left({ }^{\circ} \mathrm{C}\right)$ & Conductivimeter (Tecnopon, MCA 150 P) \\
Dissolved oxygen $\left(\mathrm{mg} \mathrm{L}^{-1}\right)$ & Oxymeter (YSI 55) \\
$\mathrm{pH}$ & Potentiometer (Tecnopon, MPA 210P) \\
Electrical conductivity $\left(\mu \mathrm{S} . \mathrm{cm}^{-3}, 25^{\circ} \mathrm{C}\right)$ & Conductivimeter (Tecnopon, MCA 150 P) \\
Water transparency $(\mathrm{m})$ & Secchi disk (30 cm diameter) \\
Suspended matter $\left(\mathrm{mg} \mathrm{L}^{-1}\right)($ Organic and inorganic particulate) & Gravimetric (Cole, 1979) \\
Total Nitrogen $\left(\mu \mathrm{gL}^{-1}\right)$ & Hach Test'n'tube (Darula, 2002) \\
Total Phosphorus $\left(\mu \mathrm{gL}^{-1}\right)$ & Stannous chloride (APHA et al., 1998) \\
Chlorophyll a & Ethanol extraction (Nusch, 1980) \\
\hline
\end{tabular}

Data on river level and rainfall volume (monthly average) were obtained from the Geological Survey of Brazil (www.cprm.br), and the measurements were made in the city of Coxim, $20 \mathrm{~km}$ upstream of the study area. The monthly physical and chemical data of the lake water (Table 2), the river level and pluviometry variables were correlated by the PCA (Principal Component Analysis) using the R program (R Core Team, 2011). The graphs of the PCA plots were separated by parameters and by lakes to show the spatial distribution considering the temporal sampling. The PCA statistical method was chosen because it is a well-established method for correlating abiotic and environmental parameters (Zuur et al., 2007; Shaukat et al., 2016).

\section{RESULTS AND DISCUSSION}

Total precipitation was $1424.8 \mathrm{~mm}$, lower than the annual average for Coxim, which is $1479.0 \mathrm{~mm}$ (https://pt.climate-data.org). During the period between 2004/2005, the occurrence of the phenomenon El Niño Southern Oscillation (ENSO) has been verified, which impacted precipitation in the Midwest region of Brazil (Marcuzzo et al., 2012; Marcuzzo and Romero 2013), decreasing the intensity of rainfall in the region. Hudson et al. (2012) observed that these phenomena have great influence on hydrology of the oxbow lakes, as they cause severe drought or rainy events. The monthly average of precipitation and the variation in the Taquari River level are shown in Figure 3, highlighting the months when the river enters the L2, which is the lake that receives water from the Taquari River only during the flood pulse in the rainy season (Panarelli et al., 2013).

Table 3 shows the values of limnological variables for the three oxbow lakes and the Taquari River. Lakes L2 (semi-connected) and L3 (connected) experienced greater variation in depth. Water transparency was higher in L1 (disconnected) and L2 lakes. In these lakes, the pH values, electrical conductivity, inorganic material, nitrogen and phosphorus were lower than in L3. These results corroborate the studies of Bayley and Guimond (2009), who observed a positive correlation between turbidity and nitrogen concentration with the entrance of the river in the lake, although the higher values in the lakes than in the river are due to the presence of macrophyte stands in those that retain and accumulate the material suspended in the water for a long period. 


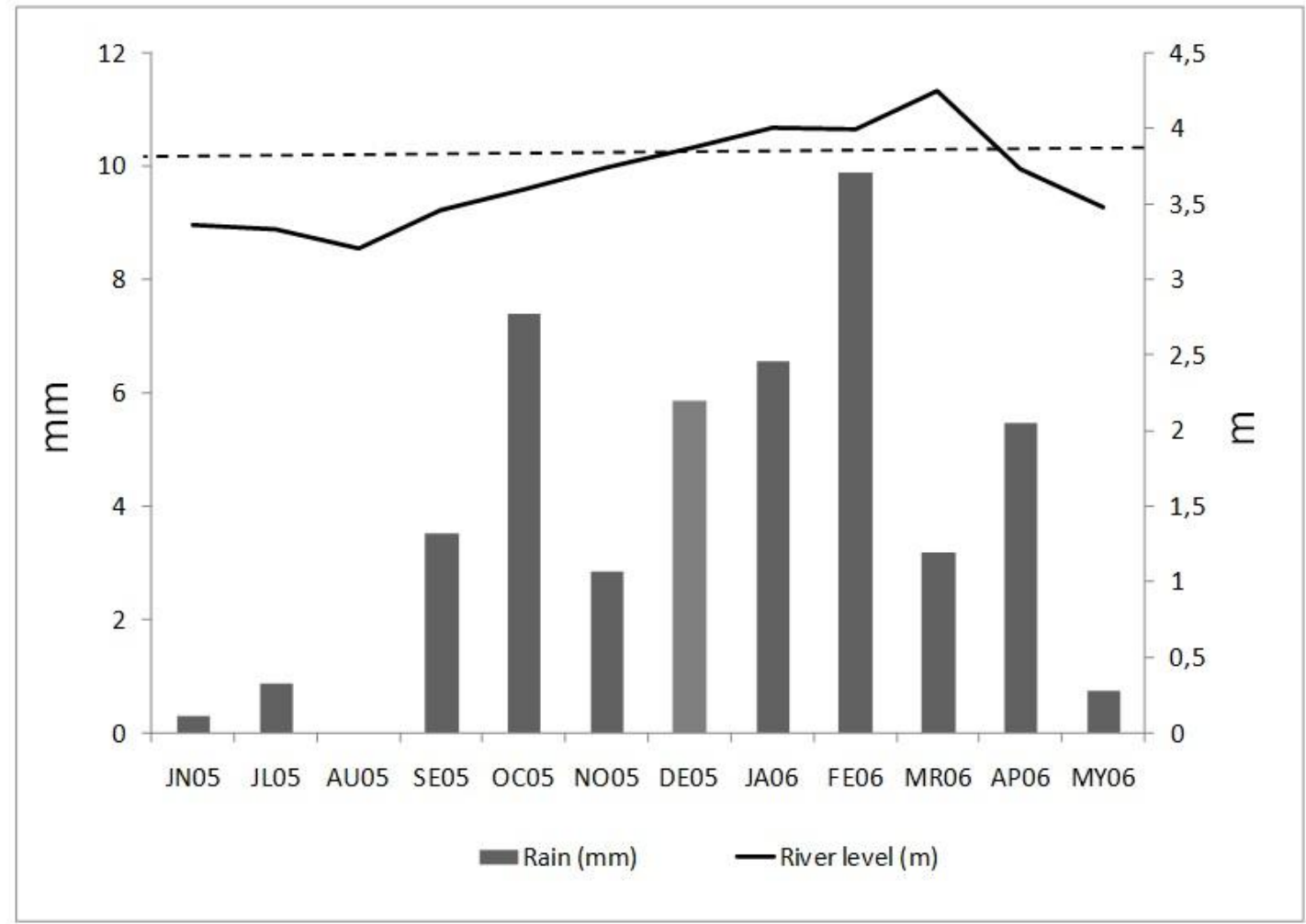

Figure 3. Precipitation ( $\mathrm{mm}$ ) in bar, water level variation $(\mathrm{m})$ in solid line. The limit of the Taquari River inflow into L2 is shown by the dashed line; inflow occurred above the river level of $3.66 \mathrm{~m}$. Modified from Panarelli et al. (2013).

Table 3. Values of the limnological variables in the oxbow lakes and the Taquari River (at the entrance of oxbow lake) as mean (minimum-maximum) from May 2005 to June 2006. L1: disconnected lake; L2: semi-connected lake and L3: connected lake.

\begin{tabular}{lcccc}
\hline & $\mathrm{L} 1$ & $\mathrm{~L} 2$ & $\mathrm{~L} 3$ & Taquari River* \\
\hline Water temperature & 26.11 & 25.89 & 28.11 & 25.34 \\
& $(21.5030 .50)$ & $(21.90-31.90)$ & $(22.3-33.00)$ & $(24.84-25.92)$ \\
Dissolved oxygen & 3.39 & 5.90 & 5.52 & 7.44 \\
& $(1.60-5.50)$ & $(3.97-7.60)$ & $(4.00-7.90)$ & $(6.19-8.10)$ \\
Electrical conductivity & 7.71 & 6.98 & 33.83 & 19.98 \\
& $(5.90-12.00)$ & $(3.40-18.87)$ & $(23.90-39.40)$ & $(12.38-23.05)$ \\
pH & 5.85 & 5.15 & 6.40 & 6.20 \\
& $(3.71-8.40)$ & $(3.46-5.80)$ & $(5.36-7.30)$ & $(5.54-6.74)$ \\
Water transparency & 1.19 & 1.28 & 0.43 & - \\
& $(0.90-1.70)$ & $(0.30-2.00)$ & $(0.15-0.76)$ & - \\
Total suspended matter & 4.11 & 13.02 & 28.36 & 8.58 \\
& $(0.00-8.00)$ & $(3.00-44.00)$ & $(6.00-120.00)$ & $(6.06-9.99)$ \\
Organic matter & 2.60 & 3.44 & 5.98 & 1.31 \\
& $(0.00-6.00)$ & $(0.00-8.00)$ & $(0.00-24.00)$ & $(1.12-1.60)$ \\
Inorganic matter & 1.52 & 9.58 & 22.38 & 7.26 \\
& $(0.00-4.00)$ & $(0.00-38.00)$ & $(6.00-96.00)$ & $(4.94-8.46)$ \\
Total phosphorus & 46.11 & 53.85 & 86.98 & - \\
& $(12.83-124.00)$ & $(10.22-102.41)$ & $(35.60-128.70)$ & - \\
Total nitrogen & 2358.33 & 2136.36 & 2663.64 & - \\
Chlorophyll a & $(800.00-6500.00)$ & $(200.00-3800.00)$ & $(500.00-5500.00)$ & - \\
& 23.84 & 8.08 & 31.95 & 2.67 \\
& $(2.80-45.10)$ & $(0,60-20.40)$ & $(11.40-47.43)$ & $(1.05-3.80)$ \\
\hline
\end{tabular}

*data from Panarelli et al. (2013). 
Lake L1 showed lower concentrations of dissolved oxygen than L2 and L3, indicating that oxygen renewal occurs in lakes under great influence of lotic systems. L2 receives the contribution of the Ribeirão do Veado stream throughout the year (Güntzel et al., 2010; Panarelli et al., 2013) and L3 was connected to the Taquari River during the entire study period. This pattern corroborates the observations made by Wantzen et al. (2005) in oxbow lakes of the Paraguay River.

The PCA (Figure 4) showed efficiency in discriminating the variables that characterized the oxbow lakes, indicating that seasonality and connectivity drove the changes of limnological variables in the three lakes studied (Figure 4a). Axis 1 shows the influence of connectivity and axis 2 shows the influence of seasonality. In the rainy season, temperatures were higher and the depth of the lakes followed the gradient of connectivity (Figures 4b, 4c and 4d). In the dry season, seasonality and connectivity drove the concentrations of nutrients (nitrogen and phosphorus) and dissolved oxygen, whose values increased in that period with the decrease in connectivity.
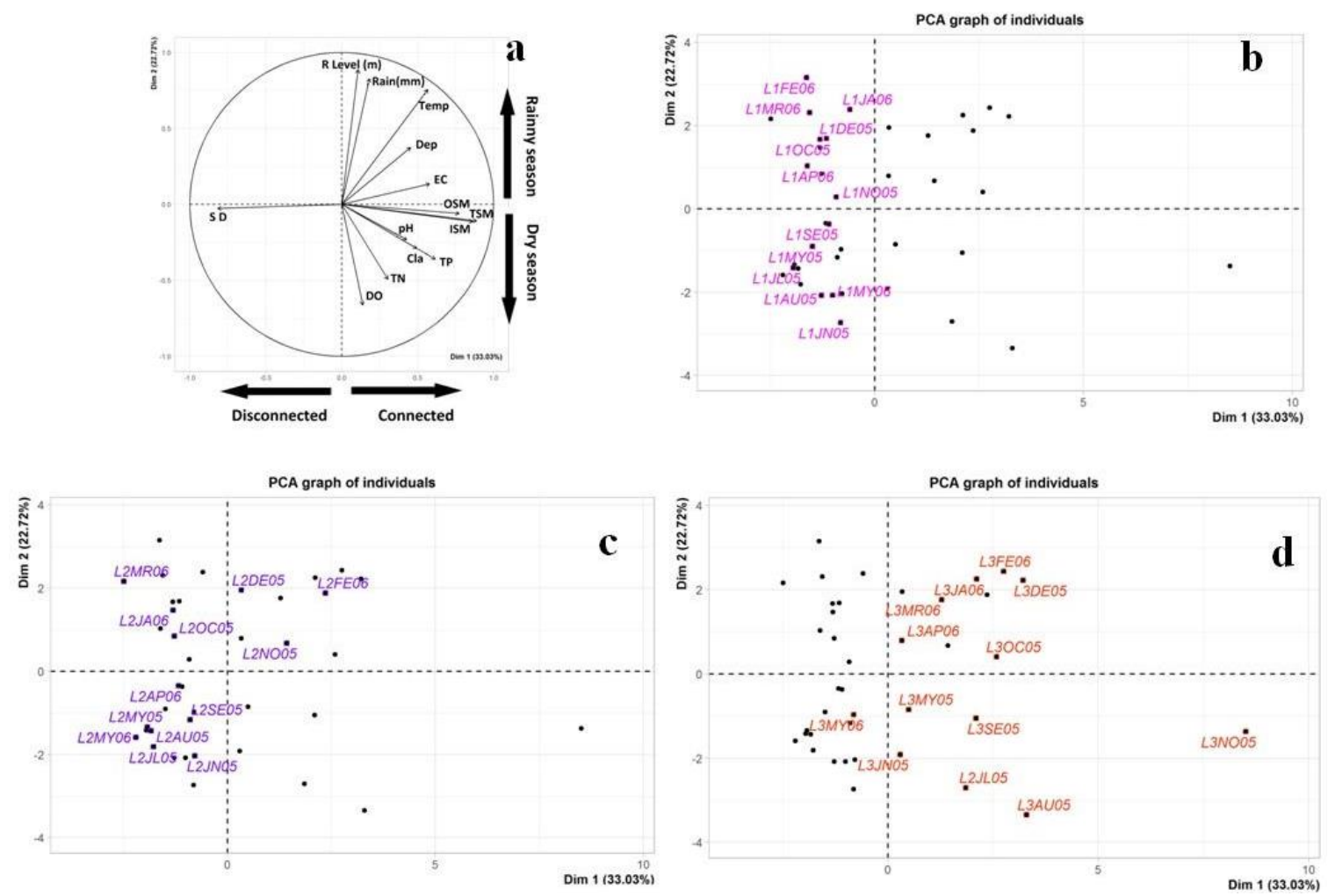

Figure 4. Principal Components analysis (PCA): a- distribution of variables on axes.SD: Secchi disc, R Level: Taquari River level, Temp: water temperature, Dep: Lake depth, EC: electric conductivity, OSM: organic suspended material, TMS: total suspended material, IMS: inorganic suspended material, TP: Total phosphorus, Cla: Chlorophyll a, TN: total nitrogen, DO: dissolved oxygen; b- L1; c- L2; d- L3.

Connectivity was the main factor in explaining the differences in concentrations of suspended material and the transparency of the water. The highest concentrations of suspended material were related to the greater connectivity of the lakes to the river and the highest values of water transparency to the least connectivity (Figure 4a). Similar observations were made by Kufel and Leśniczuck (2014), who found that the suspension of particulate materials is maintained by the constant entrance of the river and that isolated lakes have a higher sedimentation rate.

Figure $4 \mathrm{~b}$ shows the distribution of L1 points on the PCA axes. This lake, besides having the lowest values of the variables evaluated, showed the lower variation among months of dry 
and rainy season. In contrast, in L3 higher values of the variables and high range of variation were observed among the dry months. Because it is permanently connected to the Taquari River, the environmental impacts existing in its basin become a constant disturbance factor, as they interfere in lakes' water quality, as observed in this study, and in aquatic biodiversity (Güntzel et al., 2016).

On the other hand, the temporal dynamics of the disconnected lake are more conditioned by internal processes, being determined more by local seasonality than by the influence of adjacent lotic systems (Hudson et al., 2012). In oxbow lakes with a lower degree of connectivity, L1 and L2, the $\mathrm{pH}$ values were slightly more acidic during the dry season. According to Tockner et al. (2000), in disconnected aquatic environments, the internal metabolism generally promotes a reduction in $\mathrm{pH}$.

The disconnected lake (L1) receives water from a small stream; however, this connection channel is not visible and exchanges take place in the swamp area colonized by aquatic and terrestrial vegetation and by a hyporheic zone (Panarelli et al., 2013). Güntzel et al. (2016) observed that this vegetation area acts as a barrier that protects the oxbow lake from the lotic influence by filtration. The preserved riparian forest minimizes exchanges between terrestrial and aquatic systems and this barrier works efficiently against the entry of particulate matter (Newbold et al., 2010). These factors explain the higher values of transparency and lower concentrations of suspended material in the water (Table 3), taking the points of that lake to the left side of the PCA axis (Figure 4a).

In L2, intermediate values of limnological variables were observed when compared with L1 and L3. Similarly, to L1, L2 showed lower values of the variables and a small range of variation among the months in the dry season. On the other hand, the variables showed a higher range of variation in the rainy months. In this lake, river input occurred on 33\% of the days analyzed (Panarelli et al., 2013), when the river at the city of Coxim was above $3.66 \mathrm{~m}$ (Figure 3). Thus, the semi-connected lake (L2) exports water to the Taquari River for a longer period than it receives its influence.

This is a mechanism provided by the river-floodplain systems, considered an important ecosystem service, through which nutrients brought by the river are processed in the oxbow lakes and returned to the river, contributing to the cycling of materials (Costanza et al., 1997; Santos et al., 2001; Lynch et al., 2019).

Figure 4d shows the distribution of the L3 points on the PCA axes, which grouped them on the right side of axis 1 (connectivity). This lake had the least transparency of the water and the highest values of electrical conductivity, suspended material, chlorophyll-a and nutrients (Table 3). This was due to the constant entrance of the Taquari River in L3 and a drainage basin strongly impacted by agricultural activities (Galdino et al., 2005). The discharge of sediments from the plateau of the Taquari River to the plain has increased with intensive use of the soil and about $70 \%$ of this sediment is retained in the region of Coxim before the Taquari River reaches the area of influence of the Paraguay River (Risso et al., 1997; Padovani et al., 2005).

According Oliveira and Calheiros (2005), Taquari River receives waters with high concentrations of nutrients from the dairy and swine farm, in addition to those from agriculture in the Upper Taquari River Basin, making it the largest contributor of nutrients in the Paraguay River Basin (Oliveira et al., 2019). Furthermore, when the river water enters the lake, the sediment promotes eutrophication, mainly because phosphorus is transported by adsorption on sediment particles, as observed by Albuquerque and Mozeto (1997) in oxbow lakes of the Mogi-Guaçu River and Lesack and Marsh (2010) in the Mackenzie River delta.

Therefore, the intensification of deforestation in the upper Taquari River Basin and the consequent increase in the silting up of the river may result in increased environmental impacts on the floodplain. This feature, associated with the effects of climate change, can lead to changes in the range of flood pulses, in water quality and in aquatic diversity. 


\section{CONCLUSIONS}

Environmental changes caused by variations in the dry and rainy seasons influenced the limnological conditions of the studied lakes. The connectivity determined the range of variation between months and the intensity of variations in the physical and chemical characteristics of each lake during the hydrological period.

Isolation resulted in greater water transparency and smaller ranges of variation in limnological parameters throughout the hydrological period, as observed in L1. In L2, temporary connectivity, that occurs only in the rainy season, resulted in a greater range of variation between months. Loss of connectivity in the dry season altered the behavior of the lake, reducing the range of variation between months and making the limnological conditions of L2 similar to those of L1.

Permanent connectivity, seen in L3, promoted greater range of variation and higher values of limnological parameters, making this environment less transparent and more enriched with nutrients.

Limnological differences resulting from distinct degrees of connectivity between the oxbow lakes and the Taquari River established a gradient that extends over a space-time continuum, creating greater environmental heterogeneity, which can result in greater biodiversity, whose protection requires the preservation of this mosaic of lakes and the surrounding landscape.

\section{ACKNOWLEDGEMENTS}

This study was supported by Fundect - Fundação de Apoio ao Desenvolvimento do Ensino, da Ciência e Tecnologia do Estado do Mato Grosso do Sul.

\section{REFERENCES}

AB'SÁBER, A. Brasil: Paisagens de Exceção: O litoral e o Pantanal Mato-grossense Patrimônios Básicos. Cotia: Ateliê Editorial, 2006.

ALBUQUERQUE, A. L. S.; MOZETO A. A. C: N: P ratios and stable carbon isotope compositions as indicators of organic matter sources in a riverine wetland system (Mojiguaçu River, São Paulo-Brazil). Wetlands, v. 17, n. 1, p. 1-9, 1997. https://doi.org/10.1007/BF03160713

APHA; AWWA; WEF. Standard Methods for the Examination of Water and Wastewater. 20. ed. Washington, 1998.

BAYLEY, S. E.; GUIMOND, J. K. Aboveground biomass and nutrient limitation in relation to river connectivity in montane floodplain marshes. Wetlands, v. 29, n. 4, p. 1243-1254, 2009. https://doi.org/10.1672/08-227.1

COLE, G. A. Textbook of limnology. $2^{\text {nd }}$ ed. St Louis: The CV Mosby Company, 1979.

COSTANZA, R. et al. The value of the world's ecosystem services and natural capital. Nature, v. 387, n. 6630, p. $253-260,1997$. https://doi.org/10.1038/387253a0

DARULA, K. E. Total nitrogen test-N-tube reagents, alkaline persulfate digestion with colorimetric finish for the determination of total nitrogen in water and wastewater matrices. Loveland: Hach Company, 2002.

GALDINO, S.; VIEIRA, L. M.; PELLEGRIN, L. A. Impactos ambientais e socioeconômicos na Bacia do Rio Taquari-Pantanal. Corumbá: Embrapa Pantanal, 2005. 
GÜNTZEL, A. M.; PANARELLI, E. A.; SILVA, W. M.; ROCHE, K. F. Influence of connectivity on Cladocera diversity in oxbow lakes in the Taquari River floodplain (MS, Brazil). Acta Limnologica Brasiliensia, v. 2, n, 1, p. 93-101, 2010. https://dx.doi.org/10.4322/actalb.02201012

GÜNTZEL, A. M.; CAMARGO, T. V. U.; OLIVEIRA, V. F. R.; FORNARO, A. Diagnóstico do uso do solo no entorno de lagoas marginais ao rio Taquari, Bacia do Médio Taquari, Mato Grosso do Sul, Brasil, por meio de imagem de satélite LANDSAT: influência sobre a diversidade da biota aquática. In: SIMPÓSIO DE GEOTECNOLOGIAS NO PANTANAL, 6., 22-26 Oct. 2016, Cuiabá. Proceedings[...] Embrapa Informática Agropecuária; INPE, 2016. p. 897-904.

HUDSON, P. F.; HEITMULLER, F. T.; LEITCH, M. B. Hydrologic connectivity of oxbow lakes along the lower Guadalupe River, Texas: Geomorphic and climatic controls on the flood pulse concept. Journal of Hydrology, v. 414/415, p. 174-183, 2012. https://doi.org/10.1016/j.jhydrol.2011.10.029

JUNK, W. J. General Aspects of Floodplain Ecology with special Reference to amazonian floodplains. In: JUNK, W. J. (ed.). The Central Amazon Floodplain: Ecology of a pulsing System. Berlin: Spinger Verlag, 1997. p. 3-20.

JUNK, W. J.; PIEDADE, M. T. F.; LOURIVAL, R.; WITTMANN, F.; KANDUS, P.; LACERDA, L. D.; BOZELLI, R. L.; ESTEVES, F. A.; NUNES, D. A.; CUNHA, C.; MALTCHIK, L. S.; CHÖNGART, J.; SCHAEFFER-NOVELLI, Y.; AGOSTINHO, A. A. Brazilian wetlands: their definition, delineation, and classification for research, sustainable management, and protection. Aquatic Conservation, v. 24, p. 5-22, 2014. https://doi.org/10.1002/aqc.2386

JUNK, W. J.; BAYLEY, P. B.; SPARKS, R. E. The flood pulse concept in river-floodplain systems. Canadian special publication of fisheries and aquatic sciences, v. 106, n. 1, p. 110-127, 1989.

KUFEL, L.; LEŚNICZUK, S. Hydrological connectivity as most probable key driver of chlorophyll and nutrients in oxbow lakes of the Bug River (Poland). Limnologica, v. 46, p. 94-98, 2014. https://doi.org/10.1016/j.limno.2013.10.008

LESACK, L. F.W.; MARSH, P. River-to-lake connectivities, water renewal, and aquatic habitat diversity in the Mackenzie River Delta. Water Resources Research, v. 46, n. 12, 2010. https://doi.org/10.1029/2010WR009607

LYNCH, L. M.; SUTFIN, N. A.; FEGEL, T. S.; BOOT, C. M.; COVINO, T. P.; WALLENSTEIN, M. D. River channel connectivity shifts metabolite composition and dissolved organic matter chemistry. Nature communications, v. 10, n. 1, p. 1-11. 2019. https://doi.org/10.1038/s41467-019-08406-8

MARCUZZO, F. F. N.; MELO, D. C. R.; COSTA, H. C. Sazonalidade e Distribuição EspaçoTemporal das Chuvas no Bioma do Cerrado do Estado do Mato Grosso do Sul. Revista Brasileira de Recursos Hídricos, v. 17, n. 1, p. 77-86, 2012.

MARCUZZO, F. F. N.; ROMERO, V. Influência do El Niño e La Niña na precipitação máxima diária do estado de Goiás. Revista Brasileira de Meteorologia 28, 429-440. 2013. https://doi.org/10.1590/S0102-77862013000400009 
NEIFF, J. J. El regimen de pulsos en rios y grandes humedales de Sudamérica. In: MALVÁREZ, A. I.; KANDUS, P. (eds.). Tópicos sobre Grandes Humedales Sudamericanos. Montevideo: Unesco, 1997. p. 97-145.

NEWBOLD, J. D.; HERBERT, S.; SWEENEY, B. W.; KIRY, P.; ALBERTS, S. J. Water Quality Functions of a 15-Year-Old Riparian Forest Buffer System 1. JAWRA Journal of the American Water Resources Association, v. 46, n. 2, p. 299-310. 2010.

NIMER, E. Climatologia do Brasil. Rio de Janeiro: Secretaria de Planejamento e Coordenação da Presidência da Republica; IBGE, 1989. 421p.

NUSCH, E. A. Comparation of different methods for chlorophyll and phaeopigment determination. Hydrobiologie-Beiheft Ergebnisse der Limnologie, v. 14, p. 14-36, 1980 .

OLIVEIRA, M. D.; CALHEIROS, D. F. Características e alterações limnológicas na bacia do rio Taquari. In: GALDINO, S.; VIEIRA, L. M.; PELLEGIN, L. A. (eds.). Impactos Ambientais e Socioeconômicos na Bacia do Rio Taquari - Pantanal. Corumbá: Embrapa Pantanal, 2005. p. 199-208.

OLIVEIRA, M. D.; CALHEIROS, D. F.; HAMILTON, S. K. Mass balances of major solutes, nutrients and particulate matter as water moves through the floodplains of the Pantanal (Paraguay River, Brazil). RBRH, v. 24, n. e1, 2019. https://doi.org/10.1590/23180331.231820170169

PADOVANI, C. R.; GALDINO, S.; VIEIRA, L. M. Dinâmica hidrológica e de sedimentação do Rio Taquari no Pantanal. In: GALDINO, S.; VIEIRA, L. M.; PELLEGRIN, L. A. (Ed.). Impactos ambientais e socioeconômicos na Bacia do Rio Taquari - Pantanal. Corumbá: Embrapa Pantanal, 2005. p. 153-162.

PANARELlI, E. A.; GÜNTZEL, A. M.; BORGES, C. N. How does the Taquari River influence in the cladoceran assemblages in three oxbow lakes? Brazilian Journal of Biology, v. 73, n. 4, p. 717-725, 2013. https://doi.org/10.1590/S151969842013000400006

R CORE TEAM. R: A language and environment for statistical computing. Vienna: $R$ Foundation for Statistical Computing, 2011.

RISSO, A.; BORDAS, M. P.; BORGES, A. L. Produção de sedimentos. In: BRASIL. Ministério do Meio Ambiente, dos Recursos Hídricos e da Amazônia Legal. Plano de Conservação da Bacia do Alto Paraguai (Pantanal) - PCBAP: hidrossedimentologia do Alto Paraguai. Brasília, DF: MMA/PNMA, 1997. v. 2, p. 281-317.

RODRIGUES, L. C. et al. Seasonal fluctuation of some limnological variables on a floodplain lake (Patos lagoon) of the Upper Paraná River, Mato Grosso do Sul State, Brazil. Brazilian Archives of Biology and Technology, v. 45, n. 4, p. 499-513, 2002. http://dx.doi.org/10.1590/S1516-89132002000600014

SANTOS, J. E.; NOGUEIRA, F.; PIRES, J. S. R.; OBARA, A. T.; PIRES, A. M. Z. C. R. The value of the Ecological Station of Jataí's ecosystem services and natural capital. Revista Brasileira de Biolologia=Brazilian Journal of Biology, v. 61, n. 2, p. 171-190, 2001.

SHAUKAT, S.; RAO, T.; KHAN, M. A. Impact of sample size on principal component analysis ordination of an environmental data set: effects on eigenstructure, Ekológia (Bratislava), v. 35, n. 2, p. 173-190, 2016. https://doi.org/10.1515/eko-2016-0014 
TOCKNER, K.; MALARD, F.; WARD, J. V. An extension of the flood pulse concept. $\begin{array}{lllllll}\text { Hydrological processes, } & \text { v. 14, n. 16-17, p. 2861-2883, } 2000 .\end{array}$ https://doi.org/10.1002/1099-1085(200011/12)14:16/17\%3C2861::AIDHYP124\%3E3.0.CO;2-F

TOCKNER, K.; STANFORD, J. A. Riverine flood plains: present state and future trends. Environmental conservation, v. 29, n. 3, p. 308-30. 2002.

WANTZEN, K.M.; DRAGO, E.; DA SILVA, C. J. Aquatic habitats of the upper Paraguay river-floodplain-system and parts of the Pantanal (Brazil). Ecohydrology and Hydrobiology, v. 6, n. 2, p. 107-12, 2005.

WHITTAKER, R. H.; LIKENS, G. E. The biosphere and man. In: LIETH, H.; WHITTAKER, R. (eds.). Primary productivity of the biosphere. Berlin; Heidelberg: Springer, 1975. p. 305-328.

ZUUR, A.; IENO, E. N.; SMITH, G. M. Analyzing ecological data. Berlin; Heidelberg: Springer, 2007. 